\title{
Restrukturisasi Perguruan Tinggi Swasta Sebagai Upaya Penyehatan Dan Peningkatan Kualitas Institusi
}

\author{
Cita Yustisia Serfiyani \\ Fakultas Hukum Universitas Wijaya Kusuma Surabaya \\ Jln. Dukuh Kupang XXV - 54 Surabaya \\ citayustisiaserfiyani@gmail.com
}

Received: 5 Februari 2020; Accepted: 15 Juni 2020; Published: 25 Agustus 2020

DOI: 10.20885/iustum.vol27.iss2.art10

\begin{abstract}
The quantity of private universities in Indonesia that is not comparable with the fulfillment of higher education quality standards and the low quality of graduates is an important issue. Efforts to streamline the number of private universities can be pursued by restructuring legal entities, by means of mergers, consolidations, acquisitions and company separation which are of course adjusted to the character of foundations and private universities. Restructurisation is still experiencing problems that it is necessary to analyse the inhibiting and the supporting factors. This research aims to first, analyse the arrangements of legal protection for the restructurisation of private tertiary institutions, both between foundations and private tertiary institutions; second, formulating a method of restructuring private tertiary institutions that is appropriate for institutional restructurisation. This normative juridical research concludes that arrangements regarding obligation of restructurisation and the transfer of rights and obligations of the parties, first, both in restructurisation among foundations and restructurisation among private universities, need to be clarified in order to provide legal protection for the parties and the successful management of post-restructurised entities. Second, the appropriate restructurisation method to be applied is mergers and consolidations which must be supported by a new set of regulations that provide opportunities and obligation of restructurisation for private universities with certain indicators.
\end{abstract}

Key Words : Restructurisation; foundation; higher education; corpany law

\section{Abstrak}

Kuantitas perguruan tinggi swasta di Indonesia yang tidak sebanding dengan pemenuhan standar kualitas perguruan tinggi serta rendahnya kualitas lulusan menjadi isu penting. Upaya merampingkan jumlah perguruan tinggi swasta dapat ditempuh dengan restrukturisasi badan hukum, dengan cara merger, konsolidasi, akuisisi dan pemisahan perusahaan yang tentunya disesuaikan dengan karakter badan hukum yayasan dan perguruan tinggi swasta. Restrukturisasi masih mengalami kendala sehingga perlu dilakukan analisa mengenai faktor penghambat dan faktor pendukung. Penelitian ini bertujuan untuk pertama, menganalisa pengaturan pelindungan hukum terhadap restrukturisasi perguruan tinggi swasta baik yang dilakukan antar badan hukum yayasan maupun antar lembaga perguruan tinggi swasta; kedua, merumuskan metode restrukturisasi perguruan tinggi swasta yang tepat diterapkan dalam upaya penyehatan institusi. Penelitian dengan metode yuridis normatif ini menyimpulkan, pertama, pengaturan mengenai kewajiban restrukturisasi serta pengalihan hak dan kewajiban para pihak, baik dalam restrukturisasi antara yayasan maupun restrukturisasi antara perguruan tinggi swasta perlu diperjelas demi memberikan pelindungan hukum bagi para pihak dan kesuksesan pengelolaan badan pasca restrukturisasi. Kedua, metode restrukturisasi yang tepat untuk diterapkan adalah merger dan konsolidasi yang harus didukung dengan seperangkat regulasi baru yang memberikan peluang dan kewajiban restrukturisasi bagi perguruan tinggi swasta dengan indikator tertentu.

Kata-kata Kunci : Restrukturisasi; yayasan; perguruan tinggi; hukum perusahaan 


\section{Pendahuluan}

Perguruan tinggi swasta memiliki peran yang sama pentingnya dengan perguruan tinggi negeri walaupun memiliki kelebihan dan kekurangan masingmasing. ${ }^{1}$ Status kepemilikan perguruan tinggi baik dimiliki oleh pemerintah ataupun swasta bukan menjadi tolak ukur utama kualitas perguruan tinggi. Kualitas perguruan tinggi ditentukan oleh banyak faktor, misalnya seperti yang diterapkan oleh lembaga pemeringkat Quacquarelli Symonds (QS) Stars University Ratings atau "QS Stars" yakni meliputi mutu pengajaran, karir lulusan, penelitian dan internasionalisasi, kualitas lingkungan belajar, spesialisasi. ${ }^{2}$ Perguruan tinggi negeri dan swasta memiliki hak yang sama untuk menjadi yang terbaik.

Pemerintah telah berupaya memberikan perlakuan yang adil terhadap perguruan tinggi negeri dan perguruan tinggi swasta, walaupun dalam banyak hal perguruan tinggi swasta tetap harus lebih mandiri dalam pengelolaan institusi, permodalan, kerjasama, rekrutmen mahasiswa. Mengelola perguruan tinggi swasta layaknya mengelola sebuah perusahaan swasta secara mandiri. Manajemen perguruan tinggi harus dioptimalkan dengan memanfaatkan sumber daya manusia di dalamnya. ${ }^{3}$ Tentunya dengan tetap mengedepankan tujuan akademik yang bersifat non profit, sehingga perguruan tinggi swasta pasti berada di bawah naungan yayasan. Yayasan merupakan badan hukum yang bertujuan non profit. ${ }^{4}$ Sukses ataupun tidaknya pengelolaan perguruan tinggi swasta akan bergantung pula pada yayasan yang menaunginya, bukan hanya bergantung pada pejabat di tingkat fakultas dan universitas. Sinergi motivasi dan sinergi finansial menjadi penentu berhasil tidaknya restrukturisasi. ${ }^{5}$ Kerjasama yang baik antara para pihak di tingkat perguruan tinggi dan di tingkat yayasan menjadi penentu kemajuan suatu perguruan tinggi swasta.

${ }^{1}$ Kaare Aagaard, et. al., "Mergers Between Governmental Research Institutes and Universities in the Danish HE Sector", European Journal of Higher Education, Vol. 6, 2016, hlm. 41-55.

2 Situs resmi QS Stars, http://www.iu.qs.com/university-rankings/indicator-academic/\#tab-id-5, diakses tanggal 17 Januari 2020.

${ }^{3}$ Syahrizal Abbas, Manajemen Perguruan Tinggi, Prenada Media, Surabaya, 2008, hlm. 1.

4 Chatamarrasjid Ais, Hukum Yayasan : Suatu Analisis mengenai Yayasan sebagai Suatu Badan Hukum Sosial, Citra Aditya Bakti, Bandung, 2002, hlm. 1-2.

5 Donald DePamphilis, Mergers, Acquisitions, and Other Restructuring Activitites (9 ${ }^{\text {th }}$ edition), Academic Press, Massachusetts, 2017, hlm. 5-7. 
Indonesia saat ini memiliki 4.658 perguruan tinggi swasta berdasarkan data resmi dari Kemenristekdikti (sekarang Kemendikbud) di 2019.6 Jumlah ini pun belum menyebar secara demografi dan belum sebanding dengan kualitas pendidikan tinggi karena dari jumlah tersebut tidak seluruhnya aktif bahkan beberapa di antaranya menjalankan kegiatan dengan kurang mematuhi pedoman hukum. STMIK Triguna Utama sempat dipantau khusus oleh Kemenristekdikti pada 2018 lalu. Sebagaimana dalam Berita Acara Monitoring dan Evalusi Kinerja Akademik STIE ISM \& STMIK Triguna Utama berdasarkan Surat Tugas Direktur Pembinaan Kelembagaan Perguruan Tinggi Ditjen Dikti Nomor 7501/C5/KL/2018 ditemukan beberapa fakta antara lain inkonsistensi administrasi, data pendukung yang kurang dapat membuktikan kebenaran aktivitas akademik mahasiswa dan lulusan serta lemahnya penjaminan mutu akademik. Peristiwa tersebut menjadi salah satu contoh kesulitan pengelolaan universitas swasta dan sulitnya kordinasi antara lembaga dengan pemerintah yang dapat dialami dalam manajemen perguruan tinggi swasta, khususnya yang akreditasi di bawah A.

Pada saat suatu institusi terbukti melakukan pelanggaran hukum tentu beresiko pula pada pengenaan sanksi administratif, pembekuan izin, hingga pencabutan izin. Ada pula kondisi lain dimana perguruan tinggi swasta tidak melakukan pelanggaran hukum berat dan telah menjalankan kegiatannya sesuai dengan koridor hukum namun tetap saja mengalami kondisi yang kurang menguntungkan seperti kekurangan jumlah mahasiswa baru, kekurangan modal, kekurangan dosen, sulit meningkatkan akreditasi dan manajemen institusi yang belum sesuai standar ISO. Kondisi ini menyebabkan institusi tersebut kalah bersaing dengan perguruan tinggi swasta lain yang lebih unggul ataupun dengan perguruan tinggi negeri sehingga mengancam keberlangsungannya. Seperti yang dialami oleh Akademi Sekretaris dan Manajemen Purnama serta Sekolah Tinggi Ilmu Administrasi Yayasan Pembina Pendidikan Administrasi Niaga dan Negara (STIA Yappann) yang akhirnya ditutup karena tidak mendapatkan mahasiswa baru selama beberapa tahun.

Menyikapi kondisi-kondisi yang ada, perguruan tinggi swasta tentu memerlukan upaya penyehatan lembaga. Salah satu cara yang dapat diterapkan

\footnotetext{
${ }^{6}$ https://forlap.ristekdikti.go.id/perguruantinggi/homegraphpt, diakses tanggal 17 Januari 2020.
} 
adalah melalui upaya restrukturisasi badan hukum melalui merger, konsolidasi dan akuisisi. Perguruan tinggi swasta, terlepas dari perannya sebagai lembaga pendidikan yang memiliki peran luhur dalam kemajuan pendidikan juga memiliki peran sebagai badan hukum yang harus dikelola dengan baik agar tidak terjadi penurunan mutu institusi dan kerugian finansial.

Restrukturisasi perguruan tinggi swasta dapat meningkatkan kualitas akademik, kualitas riset institusi, menyehatkan keuangan lembaga serta membenahi manajemen perguruan tinggi. ${ }^{7}$ Metode restrukturisasi perguruan tinggi swasta harus dijalankan sesuai dengan kaidah hukum perusahaan dan tata kelola lembaga yang baik. Khususnya bagi perguruan tinggi swasta yang akreditasinya masih dibawah B untuk akreditasi yang dilakukan dengan mekanisme 7 standar atau masih kategori "baik" untuk akreditasi yang dilakukan dengan IAPS 4.0 dan IAPT 3.0, ${ }^{8}$ lemah dalam hal due dilligence, financial dilligence dan belum memiliki sertifikasi ISO terhadap kualitas layanan perguruan tinggi. Opsi restrukturisasi ini harus didorong pula dengan pengaturan yang jelas dan memberikan kewajiban untuk melakukan restrukturisasi.

Penelitian ini mengkaji dan meneliti mengenai aspek pelindungan hukum terhadap restrukturisasi perguruan tinggi swasta. Adapun restrukturisasi perguruan tinggi swasta sebenarnya dapat dilakukan terhadap dua atau lebih yayasan yang berbeda namun sama-sama memiliki fokus kegiatan di pendidikan tinggi, ataupun langsung terhadap lembaga perguruan tinggi swastanya saja baik perguruan tinggi swasta yang berada di bawah naungan satu yayasan yang sama. Seperti yang telah dilakukan oleh Institut Teknologi Bisnis Asia, maupun perguruan tinggi swasta di bawah naungan yayasan yang berbeda. Perbedaan cara dalam restrukturisasi perguruan tinggi swasa tersebut tentunya memiliki perbedaan aturan hukum dan metode restrukturisasi yang dapat diterapkan.

\footnotetext{
${ }^{7}$ Qiaochu Liu, et. al., "Do University Mergers Create Academic Synergy? Evidence From China and The Nordic Countries, Research Policy, Vol. 47, Issue 1, 2018, hlm. 98-107.

8Peraturan Badan Akreditasi Nasional Perguruan Tinggi Nomor 1 Tahun 2020 tentang Mekanisme Akreditasi untuk Akreditasi yang Dilakukan oleh Badan Akreditasi Nasional Perguruan Tinggi.
} 


\section{Rumusan Masalah}

Berdasarkan latar belakang di atas, maka rumusan masalah yang dikaji dalam penelitian ini adalah: pertama, bagaimana pelindungan hukum terhadap restrukturisasi perguruan tinggi swasta baik yang dilakukan antar badan hukum yayasan maupun antar lembaga perguruan tinggi swasta? Kedua, bagaimana metode restrukturisasi perguruan tinggi swasta yang tepat untuk diterapkan dalam upaya penyehatan institusi?

\section{Tujuan Penelitian}

Penelitian ini bertujuan untuk: pertama, mengkaji dan menganalisa pelindungan hukum terhadap restrukturisasi perguruan tinggi swasta baik yang dilakukan antar badan hukum yayasan maupun antar lembaga perguruan tinggi swasta; Kedua, mengkaji dan menganalisa metode restrukturisasi perguruan tinggi swasta yang tepat untuk diterapkan dalam upaya penyehatan institusi.

\section{Metode Penelitian}

Penelitian ini menggunakan metode yuridis normatif dengan pendekatan perundang-undangan (statute approach) dan pendekatan konseptual (conseptual approach). Bahan hukum primer yang digunakan meliputi UU Nomor 16 Tahun 2001 juncto UU Nomor 28 Tahun 2004 tentang Perubahan atas UU Nomor 16 Tahun 2001 tentang Yayasan, mengingat bentuk badan hukum yang menaungi perguruan tinggi swasta adalah Yayasan, disertai pula dengan UU Nomor 40 Tahun 2007 tentang Perseroan Terbatas.

Bahan hukum primer juga meliputi PP Nomor 63 Tahun 2008 tentang Pelaksanaan Undang-Undang tentang Yayasan, PP Nomor 2 Tahun 2013 tentang Perubahan atas Peraturan Pemerintah Nomor 63 Tahun 2008 tentang Pelaksanaan Undang-Undang tentang Yayasan, PP Nomor 57 Tahun 2010 tentang Penggabungan atau Peleburan Badan Usaha dan Pengambilalihan Saham Perusahaan, PP Nomor 4 Tahun 2014 tentang Penyelenggaraan Pendidikan Tinggi dan Pengelolaan Perguruan Tinggi, Perpres Nomor 44 Tahun 2016 Tentang Daftar Bidang Usaha Yang Tertutup dan Bidang Usaha Yang Terbuka Dengan Persyaratan di Bidang Penanaman Modal, Permendikbud Nomor 3 Tahun 2020 tentang Standar Nasional Pendidikan Tinggi, Permenristekdikti 
Nomor 3 Tahun 2018 tentang Penggabungan dan Penyatuan Perguruan Tinggi Swasta, Permendikbud Nomor 7 Tahun 2020 tentang Pendirian, Perubahan, Pembubaran Perguruan Tinggi Negeri dan Pendirian, Perubahan, Pencabutan Izin Perguruan Tinggi Swasta, dan lain-lain. Bahan hukum sekunder meliputi buku teks, jurnal hukum ilmiah, dan artikel ilmiah. Bahan hukum yang terkumpul kemudian dianalisis secara kualitatif.

\section{Hasil Penelitian dan Pembahasan}

Pelindungan Hukum Terhadap Restrukturisasi Perguruan Tinggi Swasta yang Dilakukan antar Badan Hukum Yayasan maupun antar Lembaga Perguruan Tinggi Swasta

Pelindungan hukum merupakan pelindungan terhadap harkat, martabat serta pengakuan terhadap hak asasi subyek hukum berdasarkan aturan hukum. ${ }^{9}$ Di samping hak, pelindungan hukum juga berkaitan dengan kewajiban negara melindungi hak warganya serta kewajiban subyek hukum dalam melakukan perbuatan hukum dengan subyek hukum lain. Aturan hukum dan perangkat penegak hukum yang ada dalam konteks restrukturisasi perguruan tinggiharus mampu memberikan pelindungan terhadap para pihak. Utamanya pelindungan yang diberikan terhadap perguruan tinggi swasta dalam posisi yang lemah antara lain karena tidak mampu memenuhi standar pendidikan nasional, kesulitan keuangan dan kekurangan jumlah tenaga pendidik dan mahasiswa.

Restrukturisasi sebagai upaya yang dapatdilakukan oleh perguruan tinggi swasta selain penutupan atau pembubaran. Restrukturisasi juga tidak akan berjalan optimal jika pengaturan hukum yang ada belum memberikan keadilan kepada para pihak. Misalnya dengan memberikan kejelasan aturan mengenai wajib atau tidaknya restrukturisasi, indikator atau kriteria kondisi perguruan tinggi swasta yang diwajibkan melakukan restrukturisasi, kejelasan metode restrukturisasi bagi perguruan tinggi swasta baik yang berada di satu yayasan yang sama dan dari yayasan yang berbeda di seluruh wilayah Indonesia.

Restrukturisasi adalah penataan ulang terhadap struktur. Tujuan restrukturisasi di antaranya demi penyehatan badan, menghindari kebangkrutan,

${ }_{9}^{9}$ Philipus M. Hadjon, Perlindungan Hukum Bagi Rakyat Indonesia, Bina Ilmu, Surabaya, 1987, hlm. 25. 
ekspansi usaha, penguasaan pasar baik nasional maupun internasional, penguasaan bahan baku dan jalur distribusi, ataupun untuk mematuhi syarat regulasi oleh Pemerintah. Restrukturisasi dilakukan dengan cara internal maupun eksternal. Restrukturisasi secara internal dilakukan dengan cara merestrukturisasi kewajiban (liability) perusahaan utamanya utang, istilah lainnya adalah restrukturisasi utang yang meliputi penundaan pembayaran, penjadwalan kembali, pengurangan/penghapusan bunga, pengurangan/penghapusan utang, konversi utang menjadi saham, penerbitan obligasi baru, penjualan barang jaminan, novasi, cessie, subrogasi sebagaimana diatur dalam KUHPerdata. Restrukturisasi badan dilakukan dengan cara mengubah bentuk atau struktur badannya. Mekanisme restrukturisasi badan/perusahaan adalah dengan cara merger, konsolidasi, akuisisi dan pemisahan perusahaan (MKAPP). ${ }^{10}$

Merger untuk badan hukum seperti Perseroan Terbatas (PT) diatur di UUPT dan peraturan pelaksananya yakni PP Nomor 27 Tahun 1998 tentang Penggabungan, Peleburan dan Pengambilalihan Perseroan Terbatas (PP 27/1998) hanya mengatur MKAPP pada bentuk PT namun hal ini bukan berarti MKAPP hanya dapat diterapkan pada PT. Restrukturisasi badan juga dapat diterapkan pada badan hukum lain seperti Koperasi, Yayasan, BUMN, BUMD hanya pilihan cara, strategi dan prosedurnya yang berbeda-beda.Konsolidasi merupakan tindakan peleburan antara dua atau lebih PT dengan cara mendirikan satu PT baru. Sementara itu, akusisi secara sederhana dapat diartikan sebagai pengambilalihan saham oleh pihak lain yang mengakibatkan beralihnya mayoritas kepemilikan perusahaan. Pemisahan perusahaan disebutkan dalam Pasal 1 angka 12 UUPT yang intinya merupakan tindakan memisahkan usaha yang mengakibatkan aktiva dan pasiva beralih, baik secara seluruhnya (split off) maupun sebagian (spin off).

PT dan Yayasan sama-sama badan hukum, namun yayasan adalah badan hukum yang tujuannya non profit. Kegiatan Yayasan didominasi oleh kegiatan yang bersifat donasi untuk tujuan sosial. ${ }^{11}$ Yayasan didirikan untuk tujuan sosial

${ }^{10}$ Ibid.

11 Theodoor Bakker, et. al., "Foundations (Yayasan) Under Indonesian Law Revisited", Oxford Journals, Volume 12, Issues 5, 2006, hlm. 16-19. 
dan membantu sesama sesuai amanat UU Yayasan, ${ }^{12}$ namun bukan berarti yayasan tidak boleh mendapatkan keuntungan dan mendirikan badan usaha. Yayasan diperbolehkan mendirikan badan usaha asalkan keuntungan yang didapatkan dikembalikan lagi untuk kepentingan pengembangan Yayasan, tidak boleh dibagikan kepada Pembina, Pengurus dan Pengawas Yayasan. Hal ini tentunya berbeda dengan PT sebagai badan hukum yang merupakan persekutuan modal, ${ }^{13}$ yang keuntungannya justru wajib dibagikan lagi kepada para pemegang saham. Sebelum terbitnya UU Nomor 28 Tahun 2004 tentang Perubahan atas UU Nomor 16 Tahun 2001 tentang Yayasan maupun UU Nomor 16 Tahun 2001 tentang Yayasan, pengaturan Yayasan lebih berpedoman pada yurisprudensi dan kegiatan Yayasan cenderung menyimpang ke arah bisnis karena belum ada kerangka regulasi sebagai pedoman. ${ }^{14}$

Badan hukum sebagai subyek hukum yang dapat bertindak mandiri dalam hukum atau dalam arti memiliki kewenangan hukum. ${ }^{15}$ Yayasan sebagai suatu legal entity yang menyandang hak dan kewajibannya sendiri. ${ }^{16}$ Tujuan utama yayasan adalah membantu kehidupan masyarakat di bidang sosial, keagamaan dan kemanusiaan. ${ }^{17}$ Yayasan merupakan badan hukum yang bertujuan filantropis. ${ }^{18}$ Yayasan memiliki "harta yang ditersendirikan" (afscheld vermogen) untuk mencapai tujuan sebagaimana ditulis dalam Anggaran Dasar dan Anggaran Rumah Tangga. ${ }^{19}$ Demi memenuhi tujuan tersebut, pembina, pengurus dan pengawas yayasan inilah yang membantu menjalankan peran Yayasan sebagai subyek hukum. Yayasan sebagai badan hukum dapat bertindak layaknya

12 Pasal 1 angka 1 UU 16/2001 juncto UU 28/2004 : Badan hukum yang terdiri atas kekayaan yang dipisahkan dan diperuntukkan mencapai tujuan tertentu di bidang sosial, keagamaan dan kemanusiaan, yang tidak mempunyai anggota.

${ }^{13}$ I Nyoman Putu Budiartha, "Pengaturan Bentuk Organisasi, Merger dan Akuisisi Perusahaan", Majalah Ilmu Hukum Kertha Wicaksana, Vol. 19 No. 2, 2013, hlm. 151-160.

${ }^{14}$ Theodoor Bakker, et. al., "Foundations (Yayasan) in Indonesian Law", Oxford Journals, Vol. 11, Issues 5, 2005, hlm. 37-39.

${ }^{15}$ Dyah Hapsari Prananingrum, “Telaah Terhadap Esensi Subjek Hukum : Manusia dan Badan Hukum”, Jurnal Refleksi Hukum, Vol. 8, No. 1, 2014, hlm. 73-92.

${ }^{16}$ Ari Purwadi, "Karakteristik Yayasan sebagai Badan Hukum di Indonesia", JurnalPerspektif, Vol. VII, No. 1, 2002, hlm. 1.

${ }^{17}$ Fendi Supriono, "Implementasi Undang-Undang Yayasan Dalam Mencapai Maksud dan Tujuan Yayasan”, Jurnal Ilmu Hukum Legal Opinion, Vol. 3, Edisi 1, 2015, hlm. 1-9.

${ }^{18}$ Dyah Hapsari Prananingrum, Hukum Yayasan di Indonesia : Kajian Filosofis dan Yuridis, Genta Publishing, Yogyakarta, 2017, hlm. 119.

${ }_{19}^{19}$ Panggabean, Penegakan Hukum Menangani Aset Yayasan, Permata Aksara, Bekasi, 2017, hlm. 4. 
subyek hukum dalam melakukan perbuatan-perbuatan hukum mulai dari membeli aset, mendirikan usaha hingga melakukan restrukturisasi terhadap badan-badan yang berada di bawah naungan yayasan.

UU 16/2001 juncto UU 28/2004 (UU Yayasan) sebenarnya telah mengatur adanya kemungkinan penggabungan atau dengan kata lain merger. UU Yayasan telah memberikan wadah bagi yayasan yang ingin melakukan restrukturisasi dalam bentuk penggabungan (merger) khususnya Pasal 57 ayat (1) UU Yayasan. Merger dapat dilakukan selama memenuhi syarat ada unsur ketidakmampuan yayasan untuk terus melaksanakan kegiatannya tanpa dukungan yayasan lain, yayasan yang menerima penggabungan dan yang bergabung kegiatannya sejenis, dan yayasan yang menggabungkan diri tidak pernah terlibat dalam perbuatan yang melanggar Anggaran Dasar yayasan, asas ketertiban umum dan kesusilaan. ${ }^{20}$ Yayasan hanya dapat dimerger dengan yayasan yang memiliki kegiatan sejenis sehingga misal ada yayasan yang bergerak di bidang panti asuhan saja, tidak dapat dimerger dengan yayasan yang berfokus di bidang pendidikan. Hal ini karena adanya ketentuan dalam Pasal 57 ayat (2) UU Yayasan, kecuali jika yayasan yang memiliki kegiatan di bidang panti asuhan tersebut dalam Akta dan Anggaran Dasarnya menyebutkan memiliki beberapa bidang kegiatan selain panti asuhan yakni pendidikan.

Cara konsolidasi atau peleburan PT telah disebutkan di UUPT namun tidak diatur di UU Yayasan untuk konsolidasi Yayasan. Cara konsolidasi sebenarnya dapat diterapkan oleh yayasan pengelola perguruan tinggi swasta di kemudian hari. Peraturan Menteri Pendidikan dan Kebudayaan Nomor 7 Tahun 2020 tentang Pendirian, Perubahan, Pembubaran Perguruan Tinggi Negeri dan Pendirian, Perubahan, Pencabutan Izin Perguruan Tinggi Swasta (Permendikbud 7/2020) juga belum mengatur mengenai cara peleburan antar lembaga perguruan tinggi swasta. Beberapa yayasan ataupun beberapa perguruan tinggi swasta yang memiliki kedudukan sama-sama lemah dapat meleburkan diri menjadi satu untuk membentuk satu entitas baru yang lebih kuat. Konsolidasi tidak mewajibkan ada satu badan yang lebih kuat posisinya karena para badan yang menyatukan diri dengan cara meleburkan dirinya tersebut membentuk satu badan baru.

${ }^{20}$ Pasal 57 ayat 2 UU 16/2001 tentang Yayasan 
Akuisisi dilakukan terhadap badan usaha yang kepemilikannya terbagi atas aset dan saham. ${ }^{21}$ Cara akuisisi tidak dapat dilakukan dalam restrukturisasi antar yayasan karena kepemilikan yayasan tidak didasarkan pada kepemilikan saham seperti dalam PT sehingga tidak ada saham yang dapat diambil alih. Yayasan bahkan tidak memiliki anggota. Rapat Pembina Yayasan merupakan pemegang kekuasaan tertinggi, bukan RUPS seperti halnya PT. Pendiri Yayasan pun bukanlah pemilik Yayasan. Pembina Yayasan selaku organ tertinggi Yayasan memiliki lima macam kewenangan antara lain membuat keputusan penggabungan atau pembubaran yayasan sebagaimana dalam Pasal 28 ayat (2) UU Yayasan.

Berhasilnya restrukturisasi perguruan tinggi swasta meliputi keberhasilan di tahap pra restrukturisasi hingga pasca restrukturisasi. Restrukturisasi badan perguruan tinggi swasta tidak hanya mengakibatkan beralihnya kepemilikan dan kendali pengelolaan badan namun juga beralihnya hak dan kewajiban termasuk aset dan utang dari badan sebelum restrukturisasi yang telah bergabung ataupun melebur dengan badan hasil restrukturisasi. Permasalahan yang dapat ditimbulkan bukan hanya sekedar masalah legalitas prosedur dan operasional badan sehari-hari namun juga mengenai status hak dan kewajiban badan. Restrukturisasi juga pasti berdampak pada hubungan hukum para pihak terkait yakni yayasan pemilik perguruan tinggi, pejabat pengelola perguruan tinggi, pengajar/dosen dan pegawai/tenaga kependidikan, mahasiswa, kreditur dan pihak ketiga yang berhubungan dengan perguruan tinggi tersebut. Oleh sebab itu, regulasi yang ada harus mampu memberikan pelindungan hukum bagi para pihak.

Mengenai hak kebendaan yang dimiliki oleh suatu badan sebelum restrukturisasi akan dilimpahkan kepada badan hasil restrukturisasi. Pengalihan aset dapat dilakukan terhadap benda bergerak dan benda tidak bergerak sebagai bagian dari aktiva badan. Hal penting berikutnya adalah mengenai perpindahan kewajiban. Pengalihan utang dalam pasiva badan juga harus dilakukan, pengalihan dapat dilakukan dengan persetujuan sejak tahap pra restrukturisasi ataupun otomatis terjadi karena undang-undang. Metodenya antara lain dengan

${ }^{21}$ Kamaludin, et. al., Restrukturisasi Merger \& Akuisisi, Mandar Maju, Bandung, 2015, hlm. 131. 
cara subrogasi ${ }^{22}$ maupun cessie ${ }^{23}$. Patut diperhatikan pula mengenai pengaturan jaminan umum pada Pasal 1131 dan 1132 BW sehingga seluruh harta kekayaan debitur baik yang sudah ada maupun yang baru akan ada di kemudian hari dianggap menjadi tanggungan untuk segala utang yang belum lunas terbayarkan apabila nilai agunan pokok dan agunan tambahan tidak mencukupi. Setelah adanya restrukturisasi, berarti harta kekayaan yang dimaksud disini adalah harta kekayaan badan hasil restrukturisasi.

Terhadap restrukturisasi yang dilakukan antara yayasan dengan yayasan maka hak dan kewajiban para pihak harus ditinjau pula dari UU Yayasan. Namun UU Yayasan hanya memberikan kepastian hukum mengenai mekanisme restrukturisasi dengan cara penggabungan (merger) saja tanpa mengatur mengenai hak dan kewajiban para pihak pasca restrukturisasi. UU Yayasan hanya menentukan hal-hal administratif yang dapat terjadi akibat restrukturisasi seperti perubahan anggaran dasar dan perubahan data yayasan sebagaimana diatur dalamPeraturan Pemerintah Nomor 63 Tahun 2008 tentang Pelaksanaan Undang Undang Tentang Yayasan, beserta tata cara penggabungan yayasan dari aspek administratif yang diatur dalam Pasal 27 sampai dengan 33 PP tersebut.

Berbeda halnya dengan pengaturan restrukturisasi Perseroan Terbatas (PT) dalam UUPT beserta peraturan pelaksananya yang lebih detail dalam membahas mengenai cara-cara restrukturisasi PT dalam upaya memberikan pelindungan hukum bagi para pihak dalam tindakan restrukturisasi PT. Hal ini dapat menimbulkan ketidakjelasan terkait prosedur restrukturisasi dan merugikan pihak perguruan tinggi swasta maupun pihak Yayasan yang menaunginya. Adapun keputusan restrukturisasi berada dalam ranah pengelola perguruan tinggi swasta dan yayasan. Perguruan Tinggi memiliki otonomi akademik dan non akademik untuk mengelola institusinya dalam melaksanakan Tridharma Perguruan Tinggi. ${ }^{24}$

\footnotetext{
${ }^{22}$ Subrogasi adalah penggantian hak-hak oleh seorang pihak ketiga yang membayar kepada kreditur dan dapat terjadi secara perjanjian maupun karena undang-undang. Subrogasi secara umum diatur di Pasal 1400-1403 KUH Perdata.

${ }^{23}$ Cessie merupakan cara pengalihan utang atas nama melalui perjanjian baik akta otentik atapun di bawah tangan. Cessie secara umum diatur di Pasal 613-624 KUH Perdata.

${ }^{24}$ Pasal 22 Peraturan Pemerintah Nomor 4 Tahun 2014 tentang Penyelenggaraan Pendidikan Tinggi dan Pengelolaan Pendidikan Tinggi.
} 
Restrukturisasi yang dilakukan antar perguruan tinggi swasta, baik dari yayasan yang sama maupun antar perguruan tinggi swasta beda yayasan, mengacu pada Permendikbud 7/2020. Permendikbud 7/2020 ini justru lebih menjelaskan cara pendirian perguruan tinggi swasta baru sehingga kurang selaras dengan program Kemendikbud yang mendorong restrukturisasi perguruan tinggi swasta. Di dalamnya juga tidak diatur mengenai kewajiban restrukturisasi perguruan tinggi baik negeri maupun swasta,pengaturan yang lebih rinci seperti pengalihan hak dan kewajiban para pihak pasca restrukturisasi pun tidak diatur, sehingga pelindungan hukum yang diberikan kepada perguruan tinggi swasta untuk melakukan restrukturisasi belum memadai.

Para pihak sementara ini mengacu pada aturan-aturan umum pada KUHPerdata, contohnya asas-asas hukum perjanjian, syarat sah perjanjian dan mekanisme jaminan umum. Di sisi lain, Pemerintah $c q$ Kemendikbud mendorong dilaksanakannya restrukturisasi perguruan tinggi swasta demi perampingan jumlah institusi dan peningkatan kualitas pendidikan namun belum diiringi dengan kepastian hukum yang dapat memberikan pelindungan hukum bagi para pihak terkait sehingga tidak adanya aturan hukum yang detail sebagai pedoman pelaksanaan dapat berdampak pada ketidakberhasilan pengelolaan perguruan tinggi pasca restrukturisasi.

\section{Metode Restrukturisasi Perguruan Tinggi Swasta yang Tepat untuk Diterapkan dalam Upaya Penyehatan Institusi}

Tujuan luhur perguruan tinggi, baik negeri maupun swasta, untuk mencerdaskan kehidupan bangsa dapat terhambat oleh adanya pelanggaranpelanggaran yang dilakukan oleh perguruan tinggi swasta itu sendiri. Di samping itu, perguruan tinggi swasta yang memiliki rekam jejak bersih tanpa kasus pelanggaran pun masih ada yang mengalami kesulitan mempertahankan dan meningkatkan akreditasi, mempertahankan jumlah mahasiswa dan kalah bersaing dengan perguruan tinggi lain yang lebih maju. Padahal komponen tersebut diperlukan dalam rangka memenuhi kewajiban standar nasional pendidikan tinggi yang semakin meningkat sejak terbitnya Permendikbud No. 3 Tahun 2020, antara lain dalam hal 
standar kompetensi lulusan, isi, proses, pendidik dan tenaga kependidikan, sarana dan prasarana, pembiayaan pendidikan, dan penilaian pendidikan.

Jumlah perguruan tinggi yang terlalu banyak namun tidak diimbangi dengan performa maksimal dikhawatirkan tidak dapat mendorong peningkatan kualitas pendidikan Indonesia namun justru menambah beban kerja Kementerian Pendidikan dan Kebudayaan dalam pembinaan dan pengawasan perguruan tinggi. Jumlah perguruan tinggi di Indonesia saat ini sangat banyak dengan jumlah seluruh perguruan tinggi 4658, terdiri dari 391 perguruan tinggi negeri dan 4267 perguruan tinggi swasta yang didominasi bentuk Sekolah Tinggi. ${ }^{25}$

Skema 1. Grafik jumlah perguruan tinggi swasta di Indonesia ${ }^{26}$

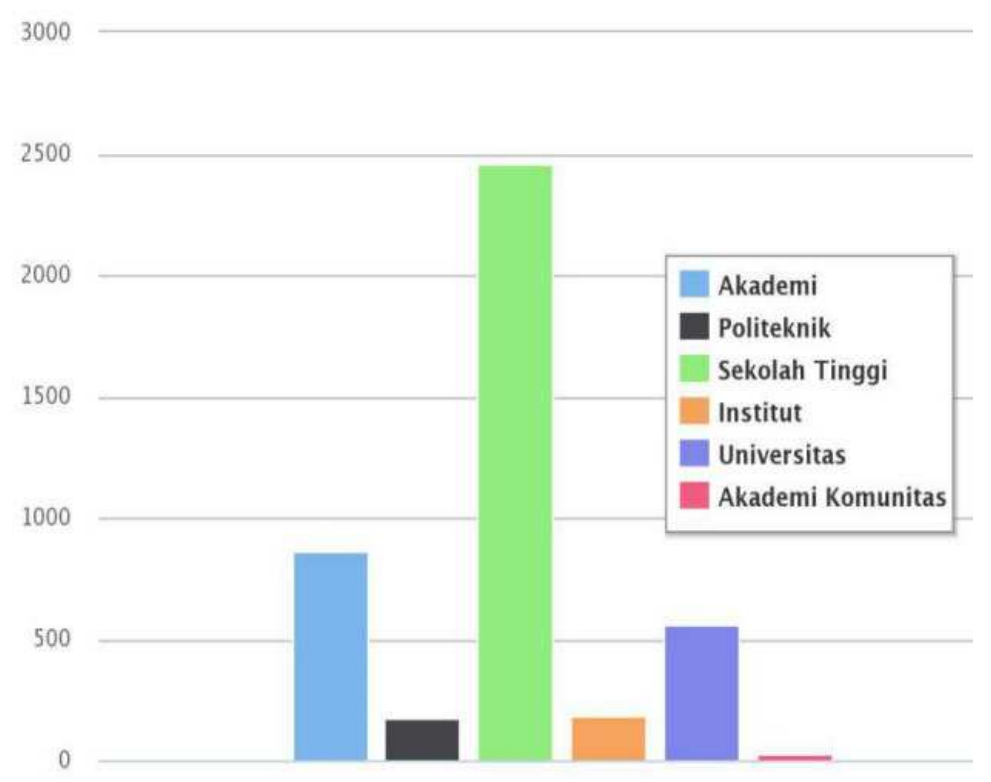

Bagi perguruan tinggi negeri, upaya perbaikan kualitas dapat dilakukan dengan cara meningkatkan status perguruan tinggi menjadi Perguruan Tinggi Negeri-Berbadan Hukum (PTN-BH). Adapun saat ini perguruan tinggi negeri dapat berstatus sebagai PTN-BH, PTN-BLU (Badan Layanan Umum), ataupun PTN Satuan Kerja. Restrukturisasi juga tetap menjadi salah satu opsi bagi perguruan tinggi negeri, seperti cara penggabungan yang dilakukan oleh Politeknik Kesehatan Pemerintah Provinsi Bengkulu milik Pemerintah Daerah

${ }^{25}$ Diakses dari situs resmi Kemenristekdikti yakni https://forlap.ristekdikti.go.id/perguruantinggi/ homegraphpt, diakses tanggal 17 Januari 2020.

${ }^{26}$ Ibid. 
Provinsi Bengkulu yang menyerahkan pengelolaannya ke Universitas Bengkulu karena pemerintah daerah tidak boleh lagi mengelola lembaga pendidikan tinggi. ${ }^{27}$

Bagi perguruan tinggi swasta, upaya penyehatan institusi dapat dilakukan dengan cara restrukturisasi internal misalnya dengan reorganisasi (perampingan, penggantian, penambahan), rekapitalisasi, revaluasi aset termasuk cara restrukturisasi utang apabila perguruan tinggi swasta tersebut tengah mengalami kesulitan finansial. Perbaikan dari segi kualitas juga dapat dilakukan dengan cara restrukturisasi badan sebagai cara restrukturisasi eksternal. Restrukturisasi perguruan tinggi swasta dapat terjadi dalam 3 kondisi: (1) restrukturisasi antara perguruan tinggi swasta di satu yayasan yang sama; (2) restrukturisasi antara perguruan tinggi swasta beda yayasan; (3) restrukturisasi antara yayasan.

Restrukturisasi perguruan tinggi merupakan salah satu upaya meningkatkan kompetensi dan kualitas perguruan tinggi. Apabila ditinjau dari opsi merger, konsolidasi, akuisisi dan pemisahan perusahaan yang sudah pasti dapat diterapkan adalah cara merger karena cara ini telah diatur dalam UU Yayasan. Target merger saat ini sebaiknya diutamakan kepada perguruan tinggi swasta dengan program studi dan jumlah peminat yang minim.

Ada kalanya satu yayasan memiliki beberapa perguruan tinggi swasta. Contohnya, merger Sekolah Tinggi Manajemen Informatika dan Komputer ASIA ke Sekolah Tinggi Ilmu Ekonomi ASIA yang sama-sama berada di bawah naungan Yayasan Wahana Edukasi Cendekia Malang. Merger telah disahkan berdasarkan SK Menristekdikti Nomor 744/KPT/I/2019. Sekolah Tinggi Ilmu Ekonomi Asia yang menerima penggabungan lantas mengubah namanya menjadi Institut Teknologi Bisnis ASIA sejak akhir 2019. Ada pula satu yayasan hanya memiliki satu perguruan tinggi swasta saja sehingga apabila ia ingin melakukan penggabungan maka penggabungan harus dilakukan dengan perguruan tinggi swasta lain yang berasal dari yayasan yang berbeda.

Tindakan penggabungan dan perampingan ini diharapkan dapat meningkatkan fokus bagi pengelola perguruan tinggi swasta maupun pengelola yayasan serta otomatis akan menghemat anggaran pendidikan yang sebelumnya

${ }^{27}$ Surat Nomor 440/923.1/DINKES/2016 dan Surat Nomor 5271/A.A3/PL/2016. 
untuk banyak lembaga menjadi satu. Merger perguruan tinggi dapat meningkatkan kualitas sistem manajemen lembaga, memperbaiki audit keuangan dan reorganisasi manajemen. ${ }^{28}$ Merger perguruan tinggi di luar negeri seperti Amerika Serikat relatif sukses dan berimplikasi positif terhadap kebijakan baru di bidang pendidikan tinggi. ${ }^{29}$

Restrukturisasi beberapa perguruan tinggi swasta yang berada di bawah naungan satu yayasan yang sama relatif lebih mudah dilakukan karena puncak kepemimpinan masih berada di bawah satu lembaga yayasan yang sama sehingga faktor pertentangan kepentingan lebih minim. Kerumitan yang akan dialami berkisar pada penyatuan pendapat, kepentingan dan ego antar pengelola universitas. Citra dan jati diri universitas pun relatif sama jika berada di bawah yayasan yang sama, semisal jika yayasan yang bernuansa muslim memiliki beberapa universitas pastilah sama-sama memiliki akar budaya Islami.

Restrukturisasi antar beberapa perguruan tinggi swasta beda yayasan serta restrukturisasi antara yayasan dengan yayasan, memiliki tantangan yang jauh lebih berat karena adanya faktor conflict interest dan ego masing-masing pihak.Faktor ego ini sebenarnya juga terjadi di merger pada jenis badan hukum lainnya terlepas dari sudah sebaik apa hasil audit finansial, audit hukum dan kelengkapan berkas persyaratan. Faktor-faktor tidak kasat mata seperti ego internal ini justru menjadi penghambat terbesar. Ditambah lagi, faktor sejarah keluarga yang telah dipertahankan secara turun temurun.

Penyatuan konsep dan citra diri universitas juga patut diperhatikan. Setiap universitas tentunya memiliki citra dan jati diri yang berbeda-beda apalagi perguruan tinggi berasal dari yayasan yang berbeda. Contohnya, penggabungan antara universitas dengan citra pendidikan islami dengan universitas dengan citra dan sistem pendidikan kristen protestan tentu akan lebih sulit dilakukan dibandingkan penggabungan antara sesama universitas islam dan penggabungan antara sesama universitasdengan sistem pendidikan kristen protestan. Penyatuan kurikulum dan

${ }^{28}$ Jarmo Saarti, et. al., "The Benefits of Quality Management System in a University Merger, a Case Study of the Merger of Two Finnish Universities", European Journal of Higher Education, Volume 2, Issue 2-3, 2012, hlm. 132-145.

${ }^{29}$ Marja Sutela, Merger of Two Universities Applied Science, buku bunga rampai Mergers in Higher Edcuation, Volume 46, Springer International Publishing, Swiss, 2016, hlm. 178. 
metode pengajaran yang jauh berbeda merupakan salah satu faktor kerumitan yang harus diperhatikan dengan tetap menjunjung tinggi bhineka tunggal ika.

Perguruan tinggi swasta yang ditargetkan untuk segara direstrukturisasi sebaiknya adalah perguruan tinggi swasta yang memiliki jumlah mahasiswa minim dibandingkan jumlah minimal kuota per angkatan. Perguruan tinggi swasta bekerja secara mandiri dalam mengelola keuangan mereka, salah satu sumber pemasukan utama adalah jumlah mahasiswa. Perguruan tinggi swasta yang kekurangan mahasiswa sebenarnya dapat disamakan dengan kondisi sebuah perusahaan yang sepi konsumen.

Restrukturisasi secara umum dapat dilakukan dengan cara merger, konsolidasi, akuisisi dan pemisahan badan. Merger dapat diterapkan pada beberapa perguruan tinggi swasta dengan persamaan level universitas untuk bergabung pada satu perguruan tinggi swasta yang lebih tinggi level atau akreditasinya dari mereka, ataupun sama level dan akreditasinya namun lebih sehat secara finansial dan sumber daya manusia. Pihak yang menerima penggabungan dalam metode merger harus jauh lebih sehat daripada pihak-pihak yang bergabung. Upaya merger atau penggabungan telah diatur dalam UU Yayasan. Prosedur merger yayasan telah diatur secara jelas pada UU Yayasan. Tindakan merger diawali dengan adanya usulan rencana penggabungan dari Dewan Pengurus masing-masing yayasan yang akan merger, usulan tersebut dituangkan dalam rancangan akta penggabungan (merger) yang disusun oleh Dewan Pengurus masing-masing yayasan tersebut. Rancangan akta penggabungan tersebut apabila sudah final ditandai dengan persetujuan dari Dewan Pembina Yayasan kepada kedua belah pihak, selanjutnya rancangan akta penggabungan tersebut dibawa ke hadapan Notaris. ${ }^{30}$ Pengurus yayasan kemudian mengumumkan hasil penggabungan dalam surat kabar harian berbahasa Indonesia maksimal 30 hari. ${ }^{31}$ Proses tersebut diikuti dengan perubahan Anggaran Dasar. Apabila perubahan Anggaran Dasar tersebut wajib disetujui oleh Menteri Hukum dan HAM maka perubahan Anggaran Dasar tersebut wajib dikirimkan kepada Menkumham dengan dilampiri akta penggabungan. ${ }^{32}$ UU

\footnotetext{
${ }^{30}$ Pasal 58-60 UU Yayasan.

${ }^{31}$ Pasal 59 UU Yayasan.

32Pasal 60 UU Yayasan.
} 
28/2004 sebagai revisi dari UU 16/2001 memperinci urusan akta yayasan yang harus disahkan oleh Menkumham. ${ }^{33}$

Cara konsolidasi juga dapat diterapkan dalam upaya restrukturisasi perguruan tinggi swasta ini. Konsolidasi dapat diterapkan pada beberapa perguruan tinggi swasta dengan level setara dan total nilai akreditasi yang sama/tidak berbeda jauh untuk kemudian mereka melebur menjadi satu dan membentuk satu perguruan tinggi swasta baru. Contoh konsolidasi beberapa perguruan tinggi swasta dari satu yayasan yang sama yang pernah terjadi adalah saat STIKES A Yani dan STMIK A Yani dari Kopertis Wilayah V D.I. Yogyakarta yang telah melebur dan melahirkan satu entitas baru bernama Universitas Jenderal Ahmad Yani. Apabila diterapkan pada konsolidasi antar yayasan, maka peleburan itu menghasilkan yayasan baru namun perguruan-perguruan tinggi swastanya tetap. Cara konsolidasi dapat menjadi opsi lain apabila masih terdapat ego dari beberapa pihak untuk bergabung dan menuruti entitas lain yang lebih tinggi levelnya. Melalui konsolidasi, susunan pemimpin pun baru, nama institusi baru, sehingga diharapkan akan lahir institusi besar baru yang sehat. Aset disatukan untuk membangun perguruan tinggi swasta baru yang lebih besar dan kekhawatiran tentang pengurangan tenaga dosen dan staf lebih dapat ditekan. Persamaan latar belakang, kepentingan dan tujuan lebih dapat dirasakan pada cara konsolidasi dibandingkan merger. Konsolidasi pada dasarnya dapat diterapkan untuk merestrukturisasi perguruan tinggi swasta ataupun yayasan, namun cara konsolidasi ini belum diatur secara jelas dalam UU Yayasan.

Akuisisi umumnya diterapkan dengan cara pengambilalihan saham. Cara ini diterapkan pada Perseroan Terbatas yang kepemilikannya terbagi atas saham. ${ }^{34}$ Baik Yayasan maupun perguruan tinggi swastanya sendiri bukan merupakan entitas yang kepemilikannya terbagi atas saham dan bahkan tidak bertujuan profit. Cara akuisisi tidak dapat diterapkan dalam konteks ini.

${ }^{33}$ Dita Bidri Riyandani, Pujiyono, "Kedudukan Yayasan Pasca Berlakunya UU Nomor 28 Tahun 2014 tentang Perubahan atas UU Nomor 16 Tahun 2001 tentang Yayasan”, Jurnal Privat Law, Vol. IV, No. 2, 2016, hlm. 152-160.

${ }^{34}$ Pengertian Perseroan Terbatas menurut Pasal 1 angka 1 UUPT : Badan hukum yang merupakan persekutuan modal, didirikan berdasarkan perjanjian, melakukan kegiatan usaha dengan modal dasar yang seluruhnya terbagi dalam saham dan memenuhi persyaratan yang ditetapkan dalam undang-undang ini serta peraturan pelaksanaannya. 
Pemisahan badan terdiri dari 2 metode yakni pemisahan sepenuhnya (split off) dan pemisahan sebagian (spin off). Pemisahan pada dasarnya dapat diterapkan pada perguruan tinggi swasta ataupun pada yayasan walaupun belum diatur secara khusus dalam UU Yayasan. Di samping itu, oleh karena penelitian ini berfokus membahas mengenai upaya perampingan jumlah institusi maka opsi ini tidak menjadi prioritas.

Upaya merger perguruan tinggi swasta memiliki kendala yakni dalam hal PTS dan/atau yayasan enggan direstrukturisasi, apalagi belum ada perangkat hukum yang mewajibkan hal ini dengan memberikan sanksi bagi yang tidak mematuhi ataupun regulasi yang dapat memberikan pelindungan hukum bagi pihak yang melakukan restrukturisasi secara sukarela. Menyikapi hal ini, dapat ditinjau mengenai kewajiban restrukturisasi yang pernah diterapkan oleh Otoritas Jasa Keuangan (OJK) terhadap Bank Pembangunan Rakyat (BPR) untuk segera melakukan salah satu opsi restrukturisasi dalam Peraturan OJK Nomor 21/POJK.03/2019 tentang Penggabungan, Peleburan dan Pengambilalihan Bank Perkreditan Rakyat dan Bank Pembiayaan Rakyat Syariah (POJK Nomor 21 Tahun 2019).

Sejak sebelum POJK Nomor 21 Tahun 2019 terbit, telah diawali lebih dulu dengan Peraturan OJK Nomor 05/POJK.03/2015 tentang Kewajiban Penyediaan Modal Minimum dan Pemenuhan Modal Inti Minimum Bank Perkreditan Rakyat (POJK Nomor 5 Tahun 2015) yang mengatur kewajiban bagi BPR yang belum memenuhi kewajiban pemenuhan modal inti sebesar Rp. 3.000.000.000,00 pada 2019 serta selanjutnya belum memenuhi kewajiban pemenuhan modal inti sebesar Rp. 5.000.000.000,00 pada 2024, maka wajib direstrukturisasi atau terpaksa bubar. Kebijakan ini ditempuh OJK untuk memenuhi target perampingan jumlah dan peningkatan daya saing BPR dengan bank umum dan lembaga keuangan lainnya, upaya ini berhasil karena selama 2014-2019 telah dilakukan proses merger terhadap 78 BPR menjadi 24 BPR, dengan kata lain jumlah BPR telah berkurang sebanyak $54 \mathrm{BPR} .{ }^{35}$

${ }^{35}$ https://www.ojk.go.id/id/kanal/perbankan/data-dan-statistik/Statistik-BPR-Konvensional/Default. aspx, diakses tanggal 17 Januari 2020. 
Hal ini merupakan contoh terjadinya restrukturisasi karena kewajiban dari Pemerintah melalui pengaturan pemenuhan target tertentu yang diatur dengan peraturan perundang-undangan. Metode ini dapat diadaptasi guna menyukseskan program restrukturisasi perguruan tinggi swasta. Penerbitan regulasi tersebut hendaknya diiringi pula oleh pemberian insentif bagi perguruan tinggi swasta yang melakukan restrukturisasi. Insentif atau kompensasi merupakan hal wajar untuk menarik minat badan dalam rencana restrukturisasi.

Dasar hukum restrukturisasi Yayasan adalah UU Yayasan. Dasar hukum tata cara penggabungan perguruan tinggi swasta juga telah ada yakni Permendikbud 7/2020. Perubahan PTS dapat terdiri atas perubahan nama dan/atau lokasi PTS, perubahan bentuk PTS, pengalihan pengelolaan PTS dari Badan Penyelenggara lama ke Badan Penyelenggara baru, penggabungan, penyatuandan/atau pemecahan dari 1 PTS menjadi 2 atau lebih PTS lain. Namun peraturan Kemendikbud tersebut hanya sebatas tata cara dan perizinan, belum ada peraturan mengenai kewajiban yang disertai pula dengan sanksi sehingga belum mampumendorong para pihak untuk aktif melakukan restrukturisasi. Kategori perguruan tinggi swasta yang akan diwajibkan melakukan restrukturisasi pun perlu untuk ditetapkan indikatornya karena tidak setiap perguruan tinggi swasta wajib melakukan restrukturisasi.

Upaya pemerintah mengurangi jumlah perguruan tinggi swasta melalui cara restrukturisasi pun belum berjalan optimal karena metode ini belum sinkron dengan Permenristekdikti Nomor 51 Tahun 2018 tentang Pendirian, Perubahan, Pembubaran Perguruan Tinggi Negeri dan Pendirian, Perubahan, Pencabutan Izin Perguruan Tinggi Swasta yang telah diubah dengan Permendikbud 7/2020. Permendikbud 7/2020 tersebut justru memiliki semangat untuk memberikan kemudahan pendirian perguruan tinggi baru.

Langkah-langkah yang sementara ini dapat dilakukan bersamaan dengan upaya pemerintah mendorong berhasilnya merger antar perguruan tinggi swasta adalah pemerintah $c q$ Kemendikbud harus mengawasi proses restrukturisasi bagi perguruan tinggi yang sudah mendaftar secara sukarela serta mengurangi sementara penerbitan ijin pendirian perguruan tinggi swasta baru. Pengawasan dilakukan agar merger melahirkan penyatuan perguruan tinggi yang lebih sehat 
dan berkualitas, sehingga tidak sembarang izin merger langsung disetujui. Di sisi lain, perlu dilakukan pencabutan izin operasional perguruan tinggi swasta yang dianggap sudah tidak memenuhi standar lagi dan tidak mau berupaya melakukan upaya restrukturisasi. Barulah selanjutnya perlu dipertimbangkan untuk mengatur kewajiban restrukturisasi bagi perguruan tinggi swasta yang tidak memenuhi indikator tertentu.

Upaya restrukturisasi ini kedepannya juga sangat mungkin membuka peluang bergabungnya perguruan tinggi swasta di bawah naungan yayasan milik asing yang didirikan di Indonesia dan sama-sama memiliki fokus kegiatan di bidang pendidikan. PP Nomor 63 Tahun 2008 tentang Pelaksanaan UndangUndang tentang Yayasan telah melegalkan pendirian yayasan milik asing di Indonesia. Orang asing dapat mendirikan Yayasan di Indonesia selama mengikuti ketentuan dalam UU Yayasan dan peraturan-peraturan pelaksananya. ${ }^{36}$ Yayasan dapat didirikan orang asing atau orang asing bersama orang Indonesia. Yayasan milik asing dapat melakukan kegiatan di sektor pendidikan. Sektor pendidikan ini telah disebutkan dalam Peraturan Presiden Nomor 44 Tahun 2016 tentang Daftar Bidang Usaha Yang Tertutup dan Bidang Usaha Yang Terbuka Dengan Persyaratan di Bidang Penanaman Modal. Sektor pendidikan menurut peraturan tersebut tergolong dalam kategori bidang usaha terbuka dengan persyaratan.

Tujuan utama dari serangkaian upaya penyehatan perguruan tinggi swasta ini akan membuat pengelola perguruan tinggi dan pengelola yayasan menjadi lebih inovatif, sehingga tidak hanya kepentingan yayasan, pejabat perguruan tinggi swasta dan dosen saja yang diutamakan namun juga kepentingan mahasiswa sebagai bagian dari sivitas akademika. Di samping berperan sebagai anak didik yang membutuhkan transfer ilmu dari perguruan tinggi, mahasiswa juga harus dipenuhi hak-haknya. Di masa ini, persaingan berjalan sangat cepat dan hanya pihak yang inovatif dan kompetitif yang dapat bertahan, termasuk persaingan yang tengah dialami oleh perguruan-perguruan tinggi swasta di sektor pendidikan tinggi.

${ }^{36}$ Berdasarkan Pasal 1 angka 6 PP Nomor 63 Tahun 2008 yang dimaksud orang asing adalah orang perseorangan asing atau badan hukum asing. 


\section{Penutup}

Penelitian ini menyimpulkan, pertama, pelindungan hukum dalam Permendikbud 7/2020 belum maksimal karena kurangnya kepastian hukum mengenai kewajiban pelaksanaan restrukturisasi serta pengalihan hak dan kewajiban para pihak, termasuk pengelolaan aset dan kepentingan pihak ketiga. Hak dan kewajiban yang dimiliki oleh Yayasan sebelum restrukturisasi beralih menjadi tanggung jawab Yayasan hasil restrukturisasi, namun UU Yayasan beserta peraturan pelaksanaannya juga belum mengatur mengenai hal tersebut.Dengan demikian, pengaturan mengenai kewajiban restrukturisasi serta pengalihan hak dan kewajiban para pihak, baik dalam restrukturisasi antara yayasan maupun restrukturisasi antara perguruan tinggi swasta perlu diperjelas demi memberikan pelindungan hukum bagi para pihak dan kesuksesan pengelolaan badan pasca restrukturisasi.

Restrukturisasi perguruan tinggi swasta dapat dilakukan dalam 3 kondisi: (a) Restrukturisasi antara perguruan tinggi swasta di satu yayasan yang sama; (b) Restrukturisasi antara perguruan tinggi swasta beda yayasan; (c) Restrukturisasi antara yayasan dengan yayasan. Restrukturisasi pada kondisi a dan b berpedoman pada Permendikbud 7/2020, karena hanya perguruan tinggi swasta sebagai institusinya saja yang melakukan restrukturisasi bukan Yayasannya. Restrukturisasi pada kondisi c berpedoman pada Permendikbud 7/2020 dan UU Yayasan. Terhadap kondisi a, b, dan c, Kemendikbud wajib memberikan pengawasan dan pelindungan hukum agar restrukturisasi perguruan tinggi swasta sejalan dengan target peningkatan kualitas pendidikan dan penyehatan institusi.

Kedua, metode restrukturisasi yang tepat diterapkan dalam restrukturisasi perguruan tinggi swasta sebagaimana dianalisis dalam penelitian ini adalah merger dan konsolidasi. Merger telah diatur dalam UU Yayasan, namun konsolidasi belum diatur secara tegas dalam UU Yayasan. Merger (Penggabungan) dan Konsolidasi (Peleburan) ini telah diatur di Permendikbud 7/2020. Cara akuisisi tidak dapat diterapkan karena kepemilikan yayasan tidak terdiri atas saham dan karakteristik yayasan sebagai lembaga non profit. Cara pemisahan badan sesungguhnya dapat diterapkan namun cara ini kurang tepat 
untuk diterapkan dalam mencapai tujuan perampingan jumlah perguruan tinggi swasta.

Penelitian ini merekomendasikan kepada Pemerintah cq Kemendikbud untuk mengatur kewajiban restrukturisasi dengan cara merger dan konsolidasi bagi perguruan tinggi swasta dengan kondisi tertentu. Perlu ditetapkan indikator perguruan tinggi swasta yang wajib direstrukturisasi sesuai urgensinya karena tidak semua perguruan tinggi swasta perlu direstrukturisasi. Penetapan regulasi tersebut hendaknya disertai kebijakan pemberian insentif, kemudahan perizinan dan fasilitas pendukung lainnya. Pemerintah juga perlu menerbitkan peraturan pemerintah terbaru sebagai peraturan pelaksana UU Yayasan yang akan memperbaharui PP 2/2013 juncto PP 63/2008 untuk mengatur lebih rinci mengenai pengalihan hak dan kewajiban para pihak beserta konsekuensinya sebagai bagian dari tata cara restrukturisasi yayasan. Metode konsolidasi juga perlu diatur dalam revisi UU Yayasan agar dapat memberikan pelindungan hukum yang tegas terhadap kemungkinan konsolidasi yayasan yang menaungi perguruan tinggi swasta.

\section{Daftar Pustaka}

\section{Buku}

Abbas, Syahrizal, Manajemen Perguruan Tinggi, Prenada Media, Surabaya, 2008.

Ais, Chatamarrasjid, Badan Hukum Yayasan : Suatu Analisis mengenai Yayasan sebagai Suatu Badan Hukum Sosial, Citra Aditya Bakti, Bandung, 2002.

De Pamphilis, Donald, Mergers, Acquisitions, and Other Restructuring Activitites (9 edition), Academic Press, Massachusetts, 2017.

Hapsari Prananingrum, Dyah, Hukum Yayasan di Indonesia : Kajian Filosofis dan Yuridis, Genta Publishing, Yogyakarta, 2017.

Kamaludin, et. al., Restrukturisasi Merger \& Akuisisi, Mandar Maju, Bandung, 2015.

M. Hadjon, Philipus, Perlindungan Hukum Bagi Rakyat Indonesia, Bina Ilmu, Surabaya, 1987.

Panggabean, Penegakan Hukum Menangani Aset Yayasan, Permata Aksara, Bekasi, 2017.

Sutela, Marja, Merger of Two Universities Applied Science, buku bunga rampai Mergers in Higher Edcuation, Volume 46, Springer International Publishing, Swiss, 2016. 


\section{Jurnal}

Ari Purwadi, "Karakteristik Yayasan sebagai Badan Hukum di Indonesia”, Jurnal Perspektif, Vol. VII, No. 1, 2002.

Dita Bidri Riyandani, Pujiyono, "Kedudukan Yayasan Pasca Berlakunya UU Nomor 28 Tahun 2014 tentang Perubahan atas UU Nomor 16 Tahun 2001 tentang Yayasan", Jurnal Privat Law, Vol. IV, No. 2, 2016.

Dyah Hapsari Prananingrum, “Telaah Terhadap Esensi Subjek Hukum : Manusia dan Badan Hukum", Jurnal Refleksi Hukum, Vol. 8, No. 1, 2014.

Fendi Supriono, "Implementasi Undang-Undang Yayasan Dalam Mencapai Maksud dan Tujuan Yayasan", Jurnal Ilmu Hukum Legal Opinion, Vol. 3, Edisi 1, 2015.

I Nyoman Putu Budiartha, "Pengaturan Bentuk Organisasi, Merger dan Akuisisi Perusahaan", Majalah Ilmu Hukum Kertha Wicaksana, Vol. 19, No. 2, 2013.

Jarmo Saarti, et. al., “The Benefits of Quality Management System in a University Merger, a Case Study of the Merger of Two Finnish Universities", European Journal of Higher Education, Vol. 2, Issue 2-3, 2012.

Kaare Aagaard, et. al., "Mergers Between Governmental Research Institutes and Universities in the Danish HE Sector", European Journal of Higher Education, Vol. 6, 2016.

Theodoor Bakker, et. al., Foundations (Yayasan) in Indonesian Law, Oxford Journals, Vol. 11, Issues 5, 2005.

Theodoor Bakker, et. al., "Foundations (Yayasan) Under Indonesian Law Revisited", Oxford Journals, Vol. 12, Issues 5, 2006.

Qiaochu Liu, et. al., “Do University Mergers Create Academic Synergy ? Evidence From China and The Nordic Countries, Research Policy, Vol. 47, Issue 1, 2018.

\section{Peraturan Perundang-undangan}

Undang-Undang Nomor 16 Tahun 2001 tentang Yayasan

Undang-Undang Nomor 28 Tahun 2004 tentang Perubahan atas UU Nomor 16 Tahun 2001 tentang Yayasan

Undang-Undang Nomor 40 Tahun 2007 tentang Perseroan Terbatas

Peraturan Pemerintah Nomor 27 Tahun 1998 tentang Penggabungan, Peleburan dan Pengambilalihan Perseroan Terbatas

Peraturan Pemerintah Nomor 63 Tahun 2008 tentang Pelaksanaan Undang Undang tentang Yayasan

Peraturan Pemerintah Nomor 57 Tahun 2010 tentang Penggabungan atau Peleburan Badan Usaha dan Pengambilalihan Saham Perusahaan 
Peraturan Pemerintah Nomor 2 Tahun 2013 tentang Perubahan atas Peraturan Pemerintah Nomor 63 Tahun 2008 tentang Pelaksanaan Undang-Undang tentang Yayasan

Peraturan Pemerintah Nomor 4 Tahun 2014 tentang Penyelenggaraan Pendidikan Tinggi dan Pengelolaan Pendidikan Tinggi

Peraturan Presiden Republik Indonesia Nomor 44 Tahun 2016 Tentang Daftar Bidang Usaha Yang Tertutup dan Bidang Usaha Yang Terbuka Dengan Persyaratan di Bidang Penanaman Modal

Peraturan OJK Nomor 05/POJK.03/2015 tentang Kewajiban Penyediaan Modal Minimum dan Pemenuhan Modal Inti Minimum Bank Perkreditan Rakyat

Peraturan OJK Nomor 21/POJK.03/2019 tentang Penggabungan, Peleburan dan Pengambilalihan Bank Perkreditan Rakyat dan Bank Pembiayaan Rakyat Syariah

Permenristekdikti Nomor 3 Tahun 2018 tentang Penggabungan dan Penyatuan Perguruan Tinggi Swasta

Peraturan Menteri Kebudayaan Nomor 3 Tahun 2020 tentang Standar Nasional Pendidikan Tinggi

Peraturan Menteri Kebudayaan Nomor 7 Tahun 2020 tentang Pendirian, Perubahan, Pembubaran Perguruan Tinggi Negeri dan Pendirian, Perubahan, Pencabutan Izin Perguruan Tinggi Swasta.

\section{Internet}

Situs resmi lembaga pemeringkat QS Star, http://www.iu.qs.com/universityrankings/indicator-academic/\#tab-id-5, diakses tanggal 17 Januari 2020.

Situs resmi Kemenristekdikti, https://forlap.ristekdikti.go.id/perguruantinggi/ homegraphpt, diakses tanggal 17 Januari 2020.

Situs resmi Otoritas Jasa Keuangan, https://www.ojk.go.id/id/kanal/ perbankan/data-dan-statistik/Statistik-BPR-Konvensional/Default.aspx, diakses tanggal 17 Januari 2020. 